\title{
Maar win je er stemmen mee? De impact van Twittergebruik door politici bij de Nederlandse Tweede Kamerverkiezingen van 12 september 2012
}

Recente studies suggereren dat Twittergebruik een (beperkt) effect heeft op het aantal voorkeurstemmen van politici. Ten tijde van die studies was Twitter echter niet wijdverspreid en was een twitterende politicus vrij uitzonderlijk. In dit artikel onderzoeken we of en hoe Twittergebruik een rol speelt als Twittergebruik wijdverspreid is onder politici. Voor de empirische testen gebruiken we een unieke dataset van 531 kandidaten tijdens de Tweede Kamerverkiezingen van 2012 en vergelijken we de resultaten met die van studies over 2010. Meer politici zijn actief op Twitter, en ze tweeten aanzienlijk meer. Ondanks het feit dat haast alle kandidaten nu twitteren, lijkt er toch nog steeds een bescheiden effect van actief tweeten op het aantal voorkeurstemmen te zijn en dit effect lijkt nu zelfs op te gaan voor politici met minder volgers. Daar staat wel tegenover dat het aantal gewonnen stemmen gemiddeld genomen aanzienlijk lager was in 2012 dan in 2010.

\section{Inleiding}

In de aanloop naar de Nederlandse Tweede Kamerverkiezingen van I2 september 20I2 volgde de Volkskrant vier kandidaten drie weken lang. Elk van hen voerde een 'persoonlijke campagne' om via voorkeurstemmen verkozen te worden. Enkel Pieter Omtzigt won voldoende voorkeurstemmen om ondanks zijn plaats op de kieslijst een zetel te winnen. De artikelenreeks geeft een mooi inzicht in hoe laaggeplaatste kandidaten vaak vol optimisme toch proberen om via een persoonlijke campagne verkozen te worden. De meeste van hen hebben nauwelijks campagnegeld en moeten met louter de steun van familie en vrienden hun doel zien te bereiken. Nederlandse politieke partijen geven weinig regie uit handen (Andeweg \& Irwin, 2005: $89)$. Bovendien gaat de media-aandacht tijdens Nederlandse campagnes toch vooral

Kristof Jacobs is aangesloten bij het departement Politicologie, Institute of Management Research van de Radboud Universiteit Nijmegen. Contact: e-mail: k.jacobs@fm.ru.nl.

Niels Spierings is aangesloten bij het departement Sociologie en CASE, beide London School of Economics and Political Science (UK). Contact: e-mail: n.spierings@lse.ac.uk 
naar de lijsttrekkers. Daarom zijn de meeste kandidaten vooral verplicht om namens de partij veel handen te schudden en te flyeren. Tegelijkertijd is er steeds meer sprake van personalisering bij de Nederlandse verkiezingen, ${ }^{\mathrm{I}}$ en zijn er recentelijk nieuwe mogelijkheden bijgekomen. Zoals Mei Li Vos het in de artikelenreeks verwoordde: 'Mijn campagne zal zich vooral online afspelen' (De Vries, 20-8-20I2). Lange tijd vereiste online campagnevoeren de hulp van gespecialiseerde techneuten en was het daardoor een dure zaak. Het hoeft dan ook niet te verwonderen dat onderzoek naar het zogenoemde 'cybercampaigning' voornamelijk vond dat het de bestaande voorsprong van de sterke kandidaten en partijen bestendigde en het de kleine partijen en minder bekende kandidaten helemaal geen grotere kans tot electoraal scoren gaf (Gibson \& McAllister, 20II). In het zogenoemde 'Equalization'versus 'Normalization'-debat is de consensus dan ook dat normalisatie, oftewel de replicatie van bestaande ongelijkheden, vaker voorkwam dan gelijkschakeling (cf. Vergeer, Hermans \& Sams, 2013). Met de komst van sociale media is dat echter veranderd. Mei Li Vos bedoelde dan ook niet dat ze een website ging lanceren met vele toeters en bellen. Ze wilde sociale media gebruiken om in contact te komen met haar potentiële achterban (zzp'ers - zelfstandigen zonder personeel).

In de breedte lijken politici inderdaad erg onder de indruk van sociale media. Bij de campagne van 20I2 was 75,5 procent van de kandidaten aanwezig op Twitter. Dat was in 20 Io nog maar 34,Iprocent. Twitter is een goedkoop en snel medium. In I40 tekens - oneliners dus - kunnen kandidaten hun boodschappen delen met hun achterban en met journalisten die in grote getale aanwezig zijn op Twitter en het medium gebruiken om citaten voor nieuwsberichten te vinden (Spierings \& Jacobs, 20I2). Politici kunnen via het medium ook makkelijk reageren op vragen van hun volgers. Twitter creëert daarmee een persoonlijke band tussen volger en politicus (Peterson, 20I2). VVD-politica Van Miltenburg geeft ten slotte ook nog mooi weer hoe politici Twitter kunnen gebruiken om in contact te komen met de samenleving: 'Sommigen weten misschien dat ik zelf geen groot twitteraar ben, maar ik weet wel dat het een krachtig medium is. Ik denk dat het een heel mooi middel kan zijn om kennis, kunde en ervaring, die in Nederland ergens is, maar waar je als parlementariër misschien nog niet tegenaan gelopen ben (sic.), hier naar binnen te halen' (Van Miltenburg, 25-09-2012).

Het is echter onduidelijk of dit alles ook echt iets oplevert in het stemhokje. Recent onderzoek gaf aan dat sociale media een bescheiden bonus bij de verkiezingen van 20I0 opgeleverd kan hebben (Kruikemeier, Van Noort \& Vliegenthart, 2013; Spierings \& Jacobs, 20I3; zie ook: Effing, Van Hillegersberg \& Huibers, 2OII). Deze studie repliceert de analyse van 2010 voor 2012 op basis van een nieuwe dataset. In 2010 was maar een klein aantal politici actief op sociale media en Twitter in het bijzonder. Het was dus makkelijk om op te vallen. In 2012 gebruikte het gros van de kandidaten Twitter en het is lang niet zeker dat het medium nog altijd een meerwaarde had. 
De centrale vraag die dit stuk wil beantwoorden is: levert Twitter voorkeurstemmen op in een campagne waarin haast iedereen het medium gebruikt? We gaan eerst in op de theorievorming rond de mogelijk causale impact van Twittergebruik op het aantal voorkeurstemmen, waarbij we ook de belangrijkste controlevariabelen behandelen om de kans op een schijnverband zo veel mogelijk te reduceren. Op basis van zelf verzamelde gegevens over 53I kandidaten bij de Nederlandse verkiezingen van 20I2, schatten we een random-intercept multiniveau regressiemodel. Het aantal voorkeurstemmen is de afhankelijke variabele en we controleren voor ballot-position en campagne-effecten (André, Wauters \& Pilet, 20I2; Gibson \& McAllister, 20I2; Lutz, 20I0; Thijssen \& Jacobs, 2004). In 20I2 blijkt er nog steeds een bescheiden effect van Twittergebruik. Maar vergeleken met de resultaten voor 20 о (Spierings \& Jacobs, 20I3) lijken ook de minder gevolgde kandidaten nu een beetje te winnen door hun Twittergebruik. Men moet echter geen wonderen verwachten van Twitter, daarvoor is het gemiddelde effect te klein.

\section{Theoretisch kader: mechanismen}

Correlatie is een belangrijk element van causaliteit, een eerste stap als het ware. Deze correlatie is echter weer weinigzeggend als er geen theoretische logica gegeven wordt waarom een verband causaal zou kunnen zijn: waarom zou Twitter een impact hebben op het aantal voorkeurstemmen? In deze paragraaf gaan we daarom in op de theoretische mechanismen die in de literatuur aangedragen worden en suggereren dat een eventuele correlatie wel eens oorzakelijkheid zou kunnen betekenen. In de literatuur worden minstens vier mechanismen onderscheiden die Twittergebruik met voorkeurstemmen verbinden: het postereffect, de symbolische waarde, het contact met nichegroepen en het contact met journalisten. De eerste drie verwijzen naar een direct effect van Twitter; contact met journalisten naar een indirect effect.

\section{Mechanismen: waarom zou Twitter een impact hebben?}

Het meest basale mechanisme ziet Twitter als een digitale campagneposter. Een kandidaat kan kiezers meer inzicht geven in haar/zijn standpunten en kan in haar/ zijn profiel en met tweets aangeven hoe zij/hij anders is dan de andere kandidaten. Twitter biedt dus de mogelijkheid om een campagne op te bouwen die de persoonlijkheid van een kandidaat centraal stelt (Vergeer, Hermans \& Sams, 20I3). Dit simpele postereffect zal wellicht vooral stemmen opleveren wanneer er weinig kandidaten zijn en nog minder Twitter gebruiken. Het tweede mechanisme gaat uit van de symbolische waarde om een Twitteraccount te hebben, aangezien het een modern imago creëert. Zo gaf de online-campagnemanager van een grote politieke partij aan dat de partij onder meer experimenteerde met Google Hangouts om 'modern over te komen' (persoonlijk interview VIRAL, 2I augustus 20I3). Het derde mechanisme focust op de mogelijkheid om via Twitter bepaalde nichegroepen te bereiken. Vooral 
voor groepen die niet geografisch geconcentreerd zijn is Twitter een laagdrempelig en geschikt campagne-instrument om contact te leggen en houden. Zo zegt kandidaat-Kamerlid Mei Li Vos: 'Heel veel kandidaten zijn regionale kandidaten, dus de Zeeuwse kandidaat of de Drentse kandidaat. En mijn achterban, de zzp'ers, die zitten overal. Dus ik kan niet zomaar overal zijn. En zzp'ers zijn in de regel allemaal online. Dus voor mij was het sowieso heel logisch, vanwege mijn doelgroep' (Vos, M.L., interview, 6 juli 2013). ${ }^{2}$

Terwijl de vorige effecten direct waren, gaat het vierde mechanisme uit van een indirect effect dat met name draait om journalisten. Het Twitterformat van korte tothe-point-boodschappen in maximaal I40 karakters is snel te lezen en makkelijk te 'quoten' door journalisten die een verhaal rond willen bouwen. Vooral tweets door prominente politici en opruiende tweets van minder bekende politici zijn interessant gebleken voor de 'oude' media (Peterson, 20I2: 432). Via deze weg kunnen minder bekende kandidaten alsnog naamsbekendheid verwerven. Twitter is daarmee 'het persoonlijke ANP' van een kandidaat (prominent Tweede-Kamerlid, persoonlijk interview, 3 juli 20I3).

Logischerwijs is te verwachten dat deze eerste twee mechanismen vooral in de 'early adoption'-fase van een nieuw campagne-instrument vruchten afwerpen. De laatste twee mechanismen zullen wellicht ook nog in een context van wijdverspreid Twittergebruik belangrijk zijn. In totaal zou men dus zelfs bij wijdverspreid gebruik een effect van Twitter kunnen verwachten op het aantal voorkeurstemmen dat een kandidaat behaalt.

Een logische vervolgvraag is dan hoe dit effect zich zal manifesteren. Simpelweg het aantal volgers vergelijken met het aantal voorkeurstemmen is niet voldoende. Kiezers volgen een bepaalde kandidaat juist omdat ze overwegen op deze persoon te stemmen of omdat ze deze persoon nu eenmaal leuk of interessant vinden. Een verband tussen beide variabelen is hoogstwaarschijnlijk een schijnverband. Interessanter is onderzoek dat kijkt naar hoe een bepaalde kandidaat potentiële kiezers via Twitter mobiliseert of overhaalt om voor hem/haar te stemmen. Zowel Kruikemeier, Van Noort en Vliegenthart (2013) als Spierings en Jacobs (2013) passen een dergelijk perspectief toe en vinden inderdaad een bescheiden effect van Twittergebruik op het aantal voorkeurstemmen. De laatsten laten zien dat de impact van het aantal volgers en het aantal tweets van elkaar afhangen. Het kan namelijk best zijn dat kandidaten veel tweeten, maar nauwelijks volgers hebben. ${ }^{3}$ De literatuur suggereert dat de kracht van sociale media vooral ook zit in het 'sneeuwbaleffect', waarbij boodschappen via opinieleiders op Twitter verder verspreid worden (Bond et al., 2012; Gibson \& McAllister, 20I2). Kandidaten die zeer veel twitteren, maar wiens tweets nauwelijks gelezen worden omdat ze weinig volgers hebben, halen ook daar weinig profijt uit. We kunnen dus het volgende verwachten: 
Hypothese I. Naarmate een kandidaat meer tweets verstuurt zal haar aantal voorkeurstemmen groter zijn, in het bijzonder als de kandidaat meer volgers heeft.

Het is echter onwaarschijnlijk dat we hier te maken hebben met een simpel lineair effect. Wanneer een kandidaat haar volgers overlaadt met tweets, zal elke extra tweet niet zomaar evenveel opleveren:

Hypothese 2. Het effect van het aantal tweets op het aantal voorkeurstemmen heeft een afnemende meeropbrengst.

\section{Controlevariabelen}

Zoals reeds vermeld, zou een significant effect van Twittergebruik op voorkeurstemmen een artefact kunnen zijn van het feit dat de kandidaat om een andere reden nu eenmaal populair is. Onze focus op het aantal tweets in plaats van louter het aantal volgers is één manier om dit probleem te vermijden. Een tweede manier is zo veel mogelijk alternatieve verklaringen voor het aantal ontvangen voorkeurstemmen op te nemen in de modellen. In de literatuur zijn twee typen verklaringen dominant: 'ballot position effects' (Geys \& Heyndels, 2003; Lutz, 20Iо; André, Wauters \& Pilet, 20I2) en campagne- en media-aandacht (Thijssen \& Jacobs, 2004; Gibson \& McAllister, 20I2).

Lijstgebonden effecten zijn gebaseerd op de gedachte dat kiezers slechts in beperkte mate in staat zijn om informatie over een groot aantal kandidaten te verzamelen en verwerken. Daarbij hebben ze geen zin om grote aantallen kandidaten grondig te bestuderen (Lutz, 20I0). Dit geldt sowieso voor Belgische en Nederlandse verkiezingen waaraan vaak grote aantallen kandidaten deelnemen. In Nederland zijn kandidaatslijsten van vijftig kandidaten per partij geen uitzondering. Deze theorie gaat ervan uit dat kiezers de lijst van boven naar beneden scannen en stoppen bij de kandidaat die hen bevalt (Lutz, 20I0: I69). ${ }^{4}$ De plek die een kandidaat bekleedt op een lijst is dus cruciaal en een prominente plek (lijsttrekker, lijstduwer) op de lijst levert de kandidaat een behoorlijk voordeel op. De eerste vrouw en eerste persoon van een etnische minderheidsgroep zullen volgens deze theorie dan ook relatief veel stemmen krijgen, aangezien sommige kiezers een symbolische of etnische stem wil uitbrengen (André, Wauters \& Pilet, 2012).

Bij campagne-effecten en media-aandacht staan drie elementen centraal: (I) de algemene ervaring van een kandidaat, (2) media-aandacht en (3) campagneactiviteiten (Thijssen \& Jacobs, 2004; Gibson \& McAllister, 20I2). Media-aandacht en campagneactiviteiten verhogen de naamsbekendheid van een kandidaat en dus de kans dat een kiezer op de kandidaat stemt. Daarbij hebben ervaren kandidaten meer campagnekennis. Welke campagneactiviteiten het meest prominent zijn, verschilt per land. Van deur tot deur gaan is bijvoorbeeld zeer populair in Angelsaksische landen (Karp, Banducci \& Bowler, 2008), maar komt minder voor in de lage landen (cf. 
Andeweg \& Irwin, 2005: 94). Hier heeft men kleinere campagneteams en zijn de belangrijkste instrumenten flyers, posters, persoonlijke webpagina's en sociale media.

\section{Data en methode}

\section{Steekproef en politiek-institutionele context}

Op I2 september 20I2 dongen 2I partijen mee naar een zetel in het Nederlandse parlement en elf partijen kregen meer stemmen dan I/150 ${ }^{\text {ste }}$ van het totaal, en dus minimaal één zetel: VVD, PvdA, PVV, CDA, SP, D66, GroenLinks, ChristenUnie, SGP, Partij voor de Dieren en nieuwkomer 50Plus. Alle 53I kandidaten van deze elf partijen (die in alle kieskringen op de lijst stonden) hebben we opgenomen in deze studie.

Voor de Tweede Kamer kent Nederland een proportioneel kiesstelsel. In de praktijk is er maar één kiesdistrict en de kiezer kan kiezen uit een groot aantal kandidaten. In tegenstelling tot België mag een Nederlandse kiezer slechts één stem uitbrengen en is er geen lijst met opvolgers. De kiezers moeten op een kandidaat stemmen. Deze voorkeurstemmen kunnen ervoor zorgen dat een kandidaat verkozen wordt ondanks een lage plaats op de lijst. Kandidaten die minimaal een kwart van de kiesdeler aan voorkeurstemmen behalen, krijgen als eerste een zetel (op voorwaarde dat de partij voldoende zetels heeft). In $20 \mathrm{I2}$ was de zogenoemde voorkeursdrempel I5.708 stemmen hoog (www.kiesraad.nl). Hoewel 26 kandidaten meer voorkeurstemmen haalden, maakte dit maar voor één kandidaat, Pieter Omtzigt, het verschil.

In de regel beheersen partijen en lijsttrekkers de campagnes. Individuele kandidaten krijgen weinig financiering om een eigen campagne te voeren. De Nederlandse campagnes zijn dan ook niet 'candidate-centered' te noemen, hoewel ze wel erg gericht zijn op personen - de lijsttrekkers (Andeweg \& Irwin, 2005: 89). De komst van goedkope sociale media zoals Twitter in combinatie met een, zoals eerder gezegd, vrij lage voorkeursdrempel, biedt kandidaten echter wel mogelijkheden. Langs de andere kant zou het kunnen dat kiezers zich ondanks de inspanningen van de kandidaten nog steeds voornamelijk richten op de lijsttrekkers. De politiekinstitutionele context biedt dus zowel voor- als nadelen voor twitterende kandidaten.

\section{Afhankelijke variabelen en modellen}

De afhankelijke variabele is het aantal stemmen dat op de kandidaat is uitgebracht. Dit aantal hangt sterk af van de partij die de kandidaat vertegenwoordigt. Daarom schatten we een multiniveau model (het MIXED commando in SPSS) waarbij het intercept varieert op het niveau van de partij (de hogere-orde-eenheid). De populariteit van de grootste stemmentrekkers op basis van hun plek op de lijst - de lijsttrekker en de eerste vrouw op de lijst - 'bepalen' vervolgens hoeveel stemmen er over de andere kandidaten te verdelen zijn. Zo kregen in 2012 de elf lijsttrekkers samen in 
totaal 8I,3 procent van de stemmen. Minder populaire lijsttrekkers (Van Haersma Buma kreeg slechts 65 procent van de CDA-stemmen) maken het voor andere kandidaten makkelijker om meer stemmen te winnen. Daarom hebben we het 'lijsttrekkerseffect' en 'eerste-vrouweffect' (zie hieronder) ook opgenomen in het random deel van het model. Een eventueel gevonden algemeen verband is dus niet vertekend door de bijzonderheden van enkele lijsttrekkers.5 De belangrijkste beschrijvende statistische informatie van variabelen is te vinden in appendix I. Deze gegevens laten zien dat de afhankelijke variabele niet normaal verdeeld is. Op basis hiervan zouden we ook kunnen kiezen voor bijvoorbeeld Poisson-regressiemodellen. Het wegfilteren van de partijspecifieke lijsttrekker- en eerste-vrouweffecten in de modellen neemt echter een groot deel van de scheefheid weg, doch niet volledig. Ter controle hebben we multiniveau Poisson-regressiemodellen geschat. We presenteren in de hoofdtekst de makkelijker te interpreteren lineaire regressiemodellen. De Poisson-regressies tonen evenwel een positieve relatie tussen het aantal tweets en voorkeurstemmen. Het effect blijft beperkt en lijkt minder sterk afhankelijk van het aantal volgers. Dit nemen we mee in onze interpretaties. De extra modellen bevestigen voornamelijk de verschuiving in het effect die we waarnemen als de analyses over 20I2 hier worden vergeleken met die van eerdere studies over 20 Iо.

\section{Onafhankelijke variabelen: Twittergebruik ${ }^{6}$}

Van alle kandidaten is bekend of ze een Twitteraccount hadden voor de verkiezingen, het aantal volgers dat ze hadden de (voor)laatste dag voor de verkiezingen en hoeveel tweets ze hebben geplaatst in de maand voor de verkiezing.7 Het aantal tweets is gemeten als het gemiddelde per dag om zo een meer universele maat te introduceren die vergelijkingen tussen studies mogelijk maakt. Alle kandidaten zonder Twitterprofiel hebben per definitie $\circ$ volgers en $\circ$ tweets geplaatst. ${ }^{8}$ Voor een korte vergelijking tussen Twitter, Hyves en Facebook aan het begin van de analyse, hebben we ook de aanwezigheid van alle 53I kandidaten op deze platforms verzameld.

Om $\mathrm{H}$ i en $\mathrm{H}_{2}$ te toetsen nemen we interactietermen en kwadratische functies van de hoofdeffecten (aantal tweets en aantal volgers) op. Aangezien we zowel interacties en kwadraten opnemen hebben we voor de volledigheid en zuiverheid ook de interacties met en van de kwadraten opgenomen. Hierdoor weten we zeker dat gevonden verbanden niet lineair worden voorgesteld terwijl ze dat niet zijn of dat we een verband over het hoofd zien door complexe interacterende meeropbrengsten. Om de hogere-ordemodellen inzichtelijk te maken visualiseren we de verbanden in figuur I.

\section{Controlevariabelen: positie op de lijst en campagnes}

Lijstgebonden effecten - De positie op de lijst is als intervalvariabele opgenomen. Een hogere waarde toont een 'lagere' positie. Een additionele dummy geeft aan of de kandidaat lijsttrekker was. Eveneens hebben we een dummy opgenomen voor lijst- 
TABEL 1: Aanwezigheid op sociale media

\begin{tabular}{llll}
\hline & Hyves & Facebook & Twitter \\
\hline Profiel (\%) & $\begin{array}{l}\text { I44/53I } \\
(27, \mathrm{I} \%)\end{array}$ & $\begin{array}{l}382 / 53 \mathrm{I} \\
(7 \mathrm{I}, 9 \%)\end{array}$ & $\begin{array}{l}40 \mathrm{I} / 53 \mathrm{I} \\
(75,5 \%)\end{array}$ \\
$\begin{array}{ll}\text { Tweets per dag } \\
\text { Gemiddelde }\end{array}$ & n.a & n.a & \\
$\begin{array}{l}\text { Mediaan } \\
\text { Maximum }\end{array}$ & & & 9,7 \\
& & & 2,7 \\
Aantal volgers & n.a & & I64,I \\
Gemiddelde & & n.a & \\
Mediaan & & & $4 . \mathrm{I} 63)$ \\
Maximum & & & 547 \\
& & & 266.478 \\
& & & $(\mathrm{n}=40 \mathrm{I})$ \\
\hline
\end{tabular}

Bron: www.ru.nl/VIRAL

duwers (de laatste twee kandidaten op de lijst). Voor de hoogstgeplaatste vrouw en hoogstgeplaatste etnisch niet-witte (of zichtbare etnische minderheids)kandidaat hebben we twee dummy's opgenomen. Met twee uitzonderingen - Jolande Sap (GroenLinks) en Marianne Thieme (PvdD) - waren alle lijsttrekkers in 20I2 blanke mannen.

Campagneactiviteiten en media-aandacht - In lijn met de literatuur (Thijssen \& Jacobs, 2004; Gibson \& McAllister, 2012; Spierings \& Jacobs, 2013) is ervaring opgenomen door te kijken of een kandidaat al Kamerlid of kabinetslid was $(\mathrm{I}=\mathrm{ja})$ en of ze in 20Io ook op de lijst stonden ( $\mathrm{I}=\mathrm{ja})$. Media-aandacht is gemeten als hoe vaak een kandidaat in de landelijke kranten ${ }^{9}$ is genoemd: voor campagne-effectiviteit gebruiken we het aantal artikelen tussen 22 augustus - de dag van het eerste lijsttrekkersdebat op tv - en de dag voor de verkiezingen; voor bredere bekendheid het aantal artikelen het jaar daarvoor (22-08-20II t/m II-08-20I2).

Daarnaast is een dummy opgenomen voor algemene bekendheid, aangezien sommige kandidaten wel bekend zijn maar niet in de kranten komen, denk daarbij aan tv-persoonlijkheden en de impact van tv op stemgedrag (Smits \& Spierings, 20I2). We beschouwen de volgende kandidaten 'bekend': voorzitters van belangrijke belangengroepen, vakbonden of werkgeversorganisaties; tv-presentatoren, nieuwslezers, opinieleiders of high-profile-activisten; en Kamer-, commissie- of partijvoorzitters, woordvoerders op nieuwswaardige portefeuilles, partijleiders en bestuurders van grote steden. ${ }^{\text {IO }}$ Ten slotte zijn effecten van online campagneactiviteiten gemeten middels een dummy voor het hebben van een eigen webpagina of -site $(I=j a) .{ }^{I I}$ 


\section{Descriptieve analyse: sociale media en Tweede Kamerkandidaten}

Het algemene sociale mediagebruik van de kandidaten illustreert goed het belang van Twitter voor deze kandidaten (zie tabel I). Drie van de vier kandidaten had een Twitteraccount. Net iets minder kandidaten had een Facebookprofiel en aanzienlijk minder (één op vier in plaats van drie op vier) een Hyvesaccount. Van de kandidaten is 88 procent actief op minimaal één van deze platforms: sociale media waren dus (zeer) wijdverspreid onder de Tweede Kamerkandidaten.

Niet alle sociale media laten hetzelfde beeld zien. Ten eerste heeft, net als in de gehele Nederlandse maatschappij, Hyves veel terrein verloren (Oosterveer, 20I3). In 20I0 was bijna nog twee op vier kandidaten actief op het medium (Spierings \& Jacobs, 20I3); twee jaar later nog één op vier. Dit medium lijkt vervangen door het internationale Facebook dat een vergelijkbare functionaliteit heeft: een persoonlijk prikbord met veel informatie en beeldmateriaal over de persoon. Twitter is veel compacter en focust op korte berichten. Facebook en Twitter kunnen dus naast elkaar bestaan en beide waren populair: van kandidaten die op het ene medium actief waren, had 78 procent ook een account op het andere medium. Twitter lijkt echter het best aan te sluiten bij campagnedoelen van individuele kandidaten. Facebook wordt meer als privémedium gebruikt, terwijl Twitter bewuster politiek wordt ingezet als eigen persbureau: kandidaten tweeten waar ze campagnevoeren, wat ze vinden van beleid, welke plannen ze hebben, en ze gebruiken Twitter om te reageren op volgers en andere politici, en om een mediaoptreden aan te kondigen (Peterson, 2012).

De aanwezigheid op Twitter van ruim 75 procent van de kandidaten is meer dan een verdubbeling ten opzichte van 20 Io (Spierings \& Jacobs, 20I3) en ook de activiteit steeg. Attje Kuiken tweette het meest met een gemiddelde van I64 tweets per dag (gemiddeld elke 9 minuten). Het gemiddelde van alle kandidaten was enkele tientallen tweets per dag. De sterke aanwezigheid van kandidaten werd echter niet weerspiegeld in een massale interesse van het publiek. Het gemiddeld aantal volgers lag op 4.I $6_{3}$ per kandidaat. Dit is grotendeels bepaald door de lijsttrekkers (gemiddeld 69.4I3) en enkele zeer 'populaire' kandidaten, zoals Arjan El-Fassed (GroenLinks), Jeanine Hennis-Plasschaert (VVD), Tofik Dibi (GroenLinks) en Mei Li Vos (PvdA) met allemaal meer dan 20.000 volgers en de eerste zelfs meer dan 250.000. De mediaan van 547 volgers geeft wellicht een beter beeld van de 'normale kandidaat'. Het aantal stemmen dat er direct gewonnen kan worden is dan ook beperkt, maar er is daarnaast wel nog het eerder vermelde mogelijke sneeuwbal- of multiplicatief effect via online en offline sociale netwerken of via de traditionele media.

\section{Verklarende analyses: de impact van Twitter op het aantal voorkeurstemmen}

Tabel 2 presenteert de kernanalyses. ${ }^{12}$ Het complexe model met verschillende hogere-ordetermen uit tabel 2 is ter verduidelijking gevisualiseerd in figuur I. De controlevariabelen tonen de verwachte effecten, wat er op duidt dat de data en het 
TABEL 2: Verklarende analyse

\begin{tabular}{|c|c|c|}
\hline & \multicolumn{2}{|c|}{$\begin{array}{l}\text { Het aantal voorkeursstemmen tijdens de Nederlandse Tweede } \\
\text { Kamerverkiezingen } 2012\end{array}$} \\
\hline & Fixed effectB-coefficient & Standaardfout \\
\hline (Constante) & 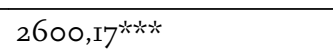 & 600,09 \\
\hline Tweets per dag & $-6,97$ & 39,47 \\
\hline Tweets per dag [kwadratisch] & $-0,08$ & 0,25 \\
\hline Aantal volgers (per I.০০০) & $-27,06$ & 164,99 \\
\hline Aantal volgers (per I.০০০) [kwadratisch] & $27,75^{*}$ & $8,4 \mathrm{I}$ \\
\hline $\begin{array}{l}\text { Interactie: Tweets per dag * Aantal volgers } \\
\text { (per I.०००) }\end{array}$ & $16,28 *$ & 8,03 \\
\hline $\begin{array}{l}\text { Interactie: Tweets per dag * Aantal volgers } \\
\text { (per I.০००) [kwadratisch] }\end{array}$ & $-I, 30 *$ & 0,39 \\
\hline $\begin{array}{l}\text { Interactie: Tweets per dag [kwadratisch] * } \\
\text { Aantal volgers (per I.000) }\end{array}$ & $-0,00$ & 0,06 \\
\hline $\begin{array}{l}\text { Interactie: Tweets per dag [kwadratisch]* } \\
\text { Aantal volgers (per I.০०0) [kwadratisch] }\end{array}$ & O,OI & O,OI \\
\hline Zittende politica ( $\mathrm{I}=\mathrm{ja})$ & -II92,90 & 686,01 \\
\hline Bekend (I=ja) & $1642,89 *$ & $742, \mathrm{II}$ \\
\hline $\begin{array}{l}\text { Aantal krantenartikelen jaar voor de cam- } \\
\text { pagne }\end{array}$ & $4^{2, \mathrm{II}}$ & 69,29 \\
\hline Aantal krantenartikelen in de campagne & $2 \mathrm{I}, 36 * * * *$ & 4,93 \\
\hline Persoonlijke website of -pagina ( $\mathrm{I}=\mathrm{ja})$ & 354,70 & 374,45 \\
\hline Campagne-ervaring ( $(=\mathrm{j} a)$ & $-270,45$ & 429,21 \\
\hline Positie op de lijst & $-70,24 * * *$ & II, 57 \\
\hline Lijsttrekker (I=ja) & $415625,04 *$ & I9282I, 87 \\
\hline Lijstduwer (I=ja) & 461,76 & 831,52 \\
\hline Eerste vrouw op de lijst ( $\mathrm{I}=\mathrm{ja})$ & $49669,15 * *$ & 19238,95 \\
\hline Vrouw (I=ja) & 433,46 & 347,47 \\
\hline Eerste niet-witte etnische kandidaat $(\mathrm{I}=\mathrm{ja})$ & $3360,83^{*}$ & $\mathrm{I} 5 \mathrm{I} 7,33$ \\
\hline Niet-witte etnische kandidaat ( $\mathrm{I}=\mathrm{ja})$ & 925,58 & 655,32 \\
\hline -2 Restricted Log Likelihood & IOI24,68 & \\
\hline BIC & IоI $68,3 \mathrm{I}$ & \\
\hline $\mathbf{N}$ & $53 \mathrm{I}$ & \\
\hline $\begin{array}{l}*=\mathrm{p}<0,05 * *=\mathrm{p}<0,0 \mathrm{I} * * * * \mathrm{p}<0,00 \mathrm{I} \\
\text { De } 53 \mathrm{I} \text { kandidaten zijn genest in de II partij } \\
\text { lijst' zijn opgenomen in het random deel va }\end{array}$ & $\begin{array}{l}\text { jen (multiniveaumodellen). } \\
\text { in het model. }\end{array}$ & ijsttrekker' en 'Eerste vrouw op de \\
\hline
\end{tabular}

Bron: Zelfverzamelde data; www.ru.nl/VIRAL

model als geheel valide zijn. De sterkste effecten vinden we voor de 'plek-op-de-lijst'variabelen. Behalve het zeer sterke effect van lijsttrekker zijn, zien we dat de eerste 
vrouw op de lijst gemiddeld zo'n 50.000 stemmen meer ontvangt en de eerste kandidaat met een niet-witte etniciteit ruim 3000 stemmen extra. Meer algemeen ontvangen kandidaten lager op de lijst minder stemmen. Ook tonen de twee belangrijkste campagne- en mediavariabelen statistisch significante effecten in de verwachte richting: 'bekende Nederlanders' krijgen een gemiddelde bonus van ruim I500 stemmen en naarmate een kandidaat vaker de krant weet te halen tijdens de campagne ontvangt deze meer stemmen. Het merendeel van de variantie (ongeveer $90 \%$ ) bevindt zich op het individuele niveau.

Ook een Twittercampagne of actief Twittergebruik lijkt enig effect te hebben, maar niet alle effecten zijn significant of duiden een causaal verband. De kwadratische term van het aantal tweets en de interactietermen daarmee zijn niet statistisch significant en laten ook substantieel geen belangrijke impact zien (in figuur I is het effect van het aantal tweets dan ook grofweg lineair). Er is geen sprake van duidelijk afnemende of toenemende meeropbrengsten. Hypothese 2 lijkt verworpen. Ten tweede krijgen kandidaten met meer volgers meer voorkeurstemmen. Dit is niet direct evident uit het hoofdeffect van het aantal volgers, maar blijkt uit de kwadratische term. Die is positief en significant, wat betekent dat naarmate het aantal volgers toeneemt het aantal voorkeurstemmen onevenredig groter wordt en op een gegeven moment is dit hoofdeffect statistisch significant. Zoals in de theoretische paragraaf al besproken is, is de gevonden correlatie tussen het aantal volgers en voorkeurstemmen echter hoogstwaarschijnlijk niet causaal.

De impact van Twittergebruik kunnen we vooral aflezen uit het effect van het aantal tweets dat een kandidaat verzendt en hoe het effect hiervan toeneemt als het publiek (het aantal volgers) toeneemt in omvang. Op basis van het hoofdeffect van het aantal tweets dat een kandidaats plaatst, blijkt dat er geen effect is als de kandidaat geen volgers heeft. Dat de interactieterm wel significant en positief is, is cruciaal en in lijn met hypothese I. Naarmate een kandidaat meer volgers heeft, neemt het effect van het aantal tweets dat de kandidaat stuurt over het algemeen toe. In dit model is het effect statistisch gesproken vanaf ongeveer I500 volgers zo sterk dat het significant is op een vijfprocentniveau. In 2012 waren er zo'n I20 kandidaten met dit aantal volgers of meer. Afhankelijk van de gebruikte methode verschilt deze grens en de kracht van de interactie wel enigszins. De cijfers hier dienen dus vooral als eerste illustratie. De significante en negatieve coëfficiënt voor de interactie van het aantal tweets met het gekwadrateerde aantal volgers geeft aan dat de toenemende impact van tweets versturen naarmate een kandidaat meer volgers heeft, afzwakt bij een zeer groot aantal volgers. Opgeteld suggereren de coëfficiënten dus dat het versturen van tweets voorkeurstemmen oplevert als een kandidaat genoeg volgers heeft, maar dat op een gegeven moment extra volgers het effect niet meer sterk verhogen. 


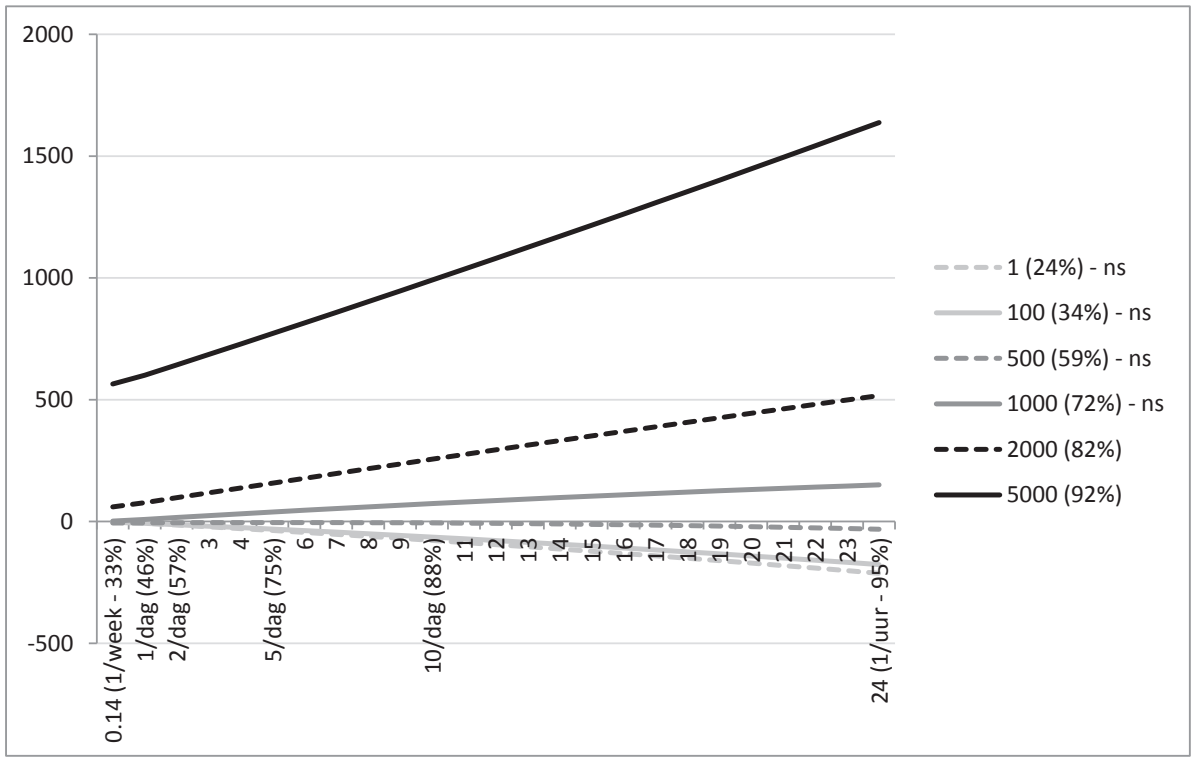

FIGUUR 1: Geschatte effecten van het aantal tweets op het aantal voorkeursstemmen Noot: (1) Op de $y$-as staat het aantal extra stemmen; op de $x$-as het aantal tweets. Bij enkele punten duiden we hoeveel kandidaten dat aantal of minder berichten plaatst. Bijvoorbeeld, 75\% van de kandidaten plaatst vijf of minder tweets per dag. (2) Om de figuur overzichtelijk te houden hebben we de impact van het aantal tweets voor een beperkt aantal volgeraantallen uitgerekend. Wederom is daar het cumulatieve percentage kandidaten met dat aantal volgers of minder bijgegeven en geduid of het effect significant is op $5 \%$.

Figuur I geeft inzicht in wat deze resultaten concreet betekenen. We zien dat er inderdaad sprake lijkt te zijn van grofweg lineaire verbanden: curves zijn met het blote oog nauwelijks waar te nemen. Wel duidelijk zichtbaar is dat het aantal tweets meer impact heeft als de kandidaat meer gevolgd wordt: de lijnen zijn steiler voor de 'populaire' kandidaten. De grafiek maakt daarbij ook inzichtelijk dat de effecten bij een zeer beperkt aantal volgers verwaarloosbaar en niet significant zijn. We moeten de impact van Twitter dus niet overschatten en in een statistische analyse is daartoe de toevoeging van interactietermen cruciaal. Ten slotte kunnen we aflezen dat een kandidaat met 5000 volgers in dit model gemiddeld een winst lijkt te kunnen boeken van ruim Iooo stemmen door elk uur te tweeten. Voor een kandidaat met 2000 volgers komt onze analyse tot een gemiddelde van bijna 500 stemmen winst. Het zal duidelijk zijn dat Twitter niet de gans met de gouden eieren is. Aan de andere kant, als Twitter onderdeel is van een bredere campagne dan kan dit aantal stemmen in een enkel geval net dat laatste beetje zijn dat nodig is om aan de (in 20I2) benodigde I5.708 voorkeurstemmen te komen. Daarbij moeten we ons 
tevens realiseren dat bij kwalitatief hoogstaand gebruik van Twitter de winst hoger zal liggen dan het gemiddelde effect dat onze statistische modellen voorspellen. ${ }^{\mathrm{I}}$

\section{Conclusie}

Op 26 augustus 2013 werd, in de gemeente Vlissingen, voor het eerst een vrouw kandidaat-volksvertegenwoordiger van de streng conservatief-religieuze partij SGP. Een van haar eerste acties als kandidaat-lijsttrekker was om - met de hulp van haar kinderen - een Twitteraccount op te zetten. Het illustreert hoe belangrijk (zelfs de 'least likely') Nederlandse partijen en kandidaten Twitter vinden. Bij hen heerst het idee dat Twitter noodzakelijk is voor succesvolle verkiezingen. Deze studie draagt bij aan het beantwoorden van de vraag of Twitter ook werkelijk voorkeurstemmen oplevert. Tot op heden werd er enkel onderzoek gedaan naar de Tweede Kamerverkiezingen van 20I0. De daar gevonden significante correlatie kon echter een artefact geweest zijn van het feit dat in 2010 slechts een klein aantal kandidaten Twitter gebruikte. Deze studie repliceert daarom deze analyses voor de verkiezingen van 20I2. Onze analyse suggereert dat Twittergebruik, ondanks het feit dat bijna alle kandidaten tegenwoordig tweeten, nog steeds een beperkt aantal voorkeurstemmen kan opleveren. Onze eerste hypothese, die stelde dat tweets meer effect hebben als men meer volgers heeft, lijkt bevestigd te worden. Onze tweede hypothese, die stelde dat meer tweeten een afnemende meeropbrengst heeft, werd daarentegen grotendeels weerlegd.

In 20 Io leverde Twitter enkel iets op voor de politici die én - voor die tijd - veel tweeten én een relatief hoog aantal volgers hadden (Spierings \& Jacobs, 20I3). ${ }^{14} \mathrm{Nu}$ is het effect breder: ook de 'kleintjes', kandidaten met een meer bescheiden gebruik en aantal volgers, hebben nu mogelijk baat bij Twitter. Echter, het aantal stemmen dat men ermee kan winnen lijkt lager geworden. In die zin heeft er een zekere nivellering plaatsgevonden. Dat is niet verwonderlijk aangezien de pool aan volgers slechts in beperkte mate is meegegroeid. Getalsmatig is de onderlinge concurrentie tussen kandidaten dus groter geworden. Een andere interessante bevinding is dat het statistische interactie-effect haast lineair lijkt te zijn. Elke tweet extra levert welhaast hetzelfde op. Samenvattend kunnen we onze centrale vraag vooralsnog bevestigend beantwoorden: ook wanneer bijna alle kandidaten Twitter gebruiken levert het iets op. De studies van Kruikemeier, Van Noort en Vliegenthart (2013) en Spierings en Jacobs (20I3) over de Nederlandse verkiezingen van 2010 zijn in die zin geen anomalie.

Twitter is een nieuw regulier campagne-instrument geworden en is uniek in haar mogelijkheden (en beperkingen). Daardoor vergt Twitter een eigen benadering en is het medium voor campagneleiders een uitdaging; kandidaten biedt het mogelijkheden om op goedkope wijze een persoonlijke campagne te voeren en op te treden als vertegenwoordiger van een specifieke achterban. In tijden waar er vanuit de 
kiezer een toenemende vraag is naar personalisering, is dat mooi meegenomen (Karvonen, 20I0: 62). Deze studie is één van een groter wordend aantal onderzoeken die suggereren dat Twittergebruik stemmen oplevert, maar om echt te kunnen spreken van causaliteit dienen deze onderzoeken getrianguleerd te worden met panelstudies, kwalitatief onderzoek en onderzoek op basis van experimenten. Ook kan er gekeken worden naar de inhoud van de tweets om te achterhalen welk soort gebruik leidt tot meer stemmen (en welk gebruik niet). Tot slot valt het op dat het meeste onderzoek in dit veld Nederlandse verkiezingen analyseert. Een laatste belangrijke piste voor verder onderzoek is dan ook om te kijken of dit effect ook in andere landen, zoals België, plaatsvindt.

Naast Twitter zijn er natuurlijk ook nog andere sociale media. Vooral Facebook is een interessant medium in tijden waar kiezers in oude democratieën steeds minder vaak traditionele media, zoals televisie en krant, gebruiken (Fletcher \& Young, 20I2: 42). Zoals een onlinecampagnemanager van een grote partij (persoonlijk interview, 2I augustus 2013) het mooi verwoordt: 'Tijdens de campagne gingen we [met Facebook] over het miljoen qua dagelijks bereik, dat is gewoon wel echt ongelooflijk als je dat vergelijkt met televisiereclame. Dat is veel duurder, maar dan heb je hetzelfde bereik.' Cybercampagnemanagers zijn zich erg bewust van de verschillen tussen de verschillende kanalen en gebruiken ze ook op verschillende wijze. Facebook lijkt een medium dat meer toelaat een persoonlijke band te krijgen en onderhouden met de kiezers. Daarbij is regelmatig contact buiten campagnetijd ook cruciaal ter voorbereiding van een latere campagne. Verder onderzoek zal zich daarom ook toe kunnen spitsen op hoe verschillende sociale media gebruikt worden en hoe ze zijn geïntegreerd in bredere campagnestrategieën.

Aan het enthousiasme van de politici zal het niet liggen. Zij lijken voornamelijk de grote potentie van Twitter te zien, ondanks de (zeer) beperkte effecten die deze en eerdere studies hebben gevonden. Toch een relativerende noot: in de inleiding citeerden we huidig Tweede Kamervoorzitter Van Miltenburg om aan te geven hoe belangrijk politici Twitter vinden. Zelf gaf ze toe geen groot Twitteraar te zijn. Dat klopt: op 2 januari 2014 had ze nog steeds geen enkele tweet verstuurd.

\section{Literatuur}

Andeweg, R.B. \& Irwin, G. (2005). Governance and politics of the Netherlands (2nd ed.). Houndmills: Palgrave MacMillan.

André, A., Wauters, B. \& Pilet, J.-B. (20I2). It's not only about lists. Explaining preference voting in Belgium. Journal of Elections, Public Opinion \& Parties, 22(3), 293-3I3.

Bond, R., Fariss, C., Jones, J., Kramer, A.D.I., Marlow, C., Settle, J.E., et al. (20I2). A 6I-million-person experiment in social influence and political mobilization. Nature, 489(7415), 295-298.

De Swert, K. (2012). Calculating inter-coder reliability in media content analysis using Krippendorffs Alpha. Working paper: http://www.polcomm.org/wp-content/uploads/ICRoIo220I2.pdf.

De Vries, J. (20-8-20I3). Strijden voor een zetel: 'Ik ben nog niet zo bezig met mezelf te verkopen'. In: de Volkskrant. 
TiJdsCHRIFT VOOR COMMUNICATIEWETENSCHAP — 42 [I] 2014

Effing, R., Van Hillegersberg, J. \& Huibers, T. (20II). Social media and political participation: Are Facebook, Twitter and YouTube democratizing our political systems? Lecture Notes in Computer Science, 6847(I), 25-35.

Fletcher, F. \& Young, M.L. (20I2). Political communication in a changing media environment. In H. Semetko \& M. Scammell (eds.) The Sage Handbook of Political Communication. London: Sage Publications Ltd.

Geys, B. \& Heyndels, B. (2003). The influence of 'cognitive sophistication' on ballot layout effects. Acta Politica, 38(4), 299-3II.

Gibson, R.K. \& McAllister, I. (20II). Do online election campaigns win votes? The 2007 Australian "youtube" election. Political Communication, 28(2), 227-244.

Gibson, R.K. \& McAllister, I. (2012, april). A net gain? Web 2.0 campaigning in the Australian 2010 election. Paper gepresenteerd op de ECPR Joint Sessions, Antwerpen, België.

Grimmer, J., Messing, S. \& Westwood, S. (2012). How words and money cultivate a personal vote. The effect of legislator credit claiming on constituent credit allocation. American Political Science Review, 106(4), 703-7i9.

Jacobs, K. \& Spierings, N. (2013, september) Loved by politicians but irrelevant at the ballot box? The diffusion of Twitter and its impact on preference voting in the Dutch general elections of 2010 and 2012. Paper gepresenteerd op de ECPR General Conference, Bordeaux, Frankrijk.

Karp, J., Banducci, S. \& Bowler, S. (2008). Getting out the vote. Party mobilization in a comparative perspective. British Journal of Political Science, 38(I), 9I-II2.

Karvonen, L. (20I0). The personalization of politics. A study of parliamentary democracies. Colchester: ECPR Press.

Kruikemeier, S., Van Noort, G. \& Vliegenthart, R. (2013, juni). The relationship between campaigning on Twitter and electoral support: present or absent? Paper gepresenteerd op de Annual Conference of the International Communication Association, London, Verenigd Koninkrijk.

Lutz, G. (20IO). First come, first served: the effect of ballot position on electoral success in open ballot PR elections. Representation, 46(2), I67-I8I.

Oosterveer, D. (2013). Social media in Nederland 20I3: Groei van gebruik Twitter en Facebook afgevlakt. Geraadpleegd op I3 augustus 20I3 via http://www.marketingfacts.nl/berichten/social-media-in-nederland-twitter-en-facebook-het-meest-actief-gebruikt.

Peterson, R. (2012). To tweet or not to tweet: Exploring the determinants of early adoption of Twitter by House members in the IIIth Congress. The Social Science Journal, 49(4), 430-438.

Smits, F. \& Spierings, N. (20I2). Sociale integratie en het kijken naar nieuwsprogramma's als determinanten voor het wisselen van politieke partijkeuze in de periode i994-2006. Mens en Maatschappij, $87(2)$, I50-I73.

Spierings, N. \& Jacobs, K. (20I2). Marginal but significant. The impact of social media on preferential voting. IMR Working paper POLı2-oI.

Spierings, N. \& Jacobs, K. (2013). Getting personal? The impact of social media on preferential voting. Political Behavior, doi: 10.1007/si1109-013-9228-2.

Thijssen, P. \& Jacobs, K. (2004). Determinanten van voorkeurstemproporties bij (Sub)locale Verkiezingen. De Antwerpse districtsraadsverkiezingen van 8 oktober 2000. Res Publica, 46(4), 460-485.

Vergeer, M., Hermans, L. \& Sams, S. (20I3). Online social networks and micro-blogging in political campaigning. The exploration of a new campaign tool and a new campaign style. Party Politics, 19(5), 477-501.

Van Holsteyn J. \& Andeweg, R. (20I2). Tweede orde personalisering; Voorkeurstemmen in Nederland. Res Publica, 54(2), I63-I9I. 


\section{Appendix A. Descriptieve informatie}

\begin{tabular}{lrrrrr}
\hline Variabele & N & Min & Max & Gem. & $\begin{array}{r}\text { Standaard- } \\
\text { afwijking }\end{array}$ \\
\hline Voorkeurstemmen & $53 \mathrm{I}$ & 75 & 2.129 .000 & $\mathrm{I} 7 \cdot 534,05$ & $\mathrm{I} 36.460,6 \mathrm{I}$ \\
Tweets per dag & $53 \mathrm{I}$ & $\circ$ & $\mathrm{I} 64, \mathrm{IO}$ & $7,3 \mathrm{I}$ & 24,33 \\
Aantal volgers (per I.000) & $53 \mathrm{I}$ & $\circ$ & 266,48 & $3, \mathrm{I} 4$ & $\mathrm{I} 8,07$ \\
Zittende politica (I=ja) & $53 \mathrm{I}$ & $\circ$ & $\mathrm{I}$ & $0, \mathrm{I} 9$ & 0,39 \\
Bekend (I=ja) & $53 \mathrm{I}$ & $\circ$ & $\mathrm{I}$ & $0, \mathrm{II}$ & $0,3 \mathrm{I}$ \\
Aantal krantenartikelen jaar voor de campagne & $53 \mathrm{I}$ & $\circ$ & 597 & 7,69 & 45,40 \\
Aantal krantenartikelen in de campagne & $53 \mathrm{I}$ & $\circ$ & 3.000 & 53,09 & 222,78 \\
Persoonlijke website of -pagina (I=ja) & $53 \mathrm{I}$ & $\circ$ & $\mathrm{I}$ & 0,42 & 0,49 \\
Campagne-ervaring (I=ja) & $53 \mathrm{I}$ & $\circ$ & $\mathrm{I}$ & 0,40 & 0,49 \\
Positie op de lijst & $53 \mathrm{I}$ & $\mathrm{I}$ & 75 & 27,07 & $\mathrm{I}, 77$ \\
Lijsttrekker (I=ja) & $53 \mathrm{I}$ & $\circ$ & $\mathrm{I}$ & 0,02 & $0, \mathrm{I} 4$ \\
Lijstduwer (I=ja) & $53 \mathrm{I}$ & $\circ$ & $\mathrm{I}$ & 0,04 & 0,20 \\
Eerste vrouw op de lijst (I=ja) & $53 \mathrm{I}$ & $\circ$ & $\mathrm{I}$ & 0,02 & $0, \mathrm{I} 4$ \\
Vrouw (I=ja) & $53 \mathrm{I}$ & $\circ$ & $\mathrm{I}$ & 0,34 & 0,47 \\
Eerste niet-witte etnische kandidaat (I=ja) & $53 \mathrm{I}$ & $\circ$ & $\mathrm{I}$ & 0,02 & $0, \mathrm{I} 2$ \\
Niet-witte etnische kandidaat (I=ja) & $53 \mathrm{I}$ & $\circ$ & $\mathrm{I}$ & 0,08 & 0,27 \\
\hline
\end{tabular}

Bron: zelf verzamelde data (www.ru.nl/VIRAL)

\section{Noten}

I Al blijft deze relatief bescheiden (Van Holsteyn \& Andeweg, 20I2).

2 Uiteraard zullen sommige volgers de inhoud van sommige tweets negatief beoordelen. Toch kunnen we ervan uitgaan dat het netto-effect positief is aangezien een groot deel van dit causale mechanisme loopt via simpele naamsbekendheid (Grimmer, Messing \& Westwood, 20I2).

3 Enkele voorbeelden uit 20I2: Anne Scheltema Beduin (GroenLinks) stuurde gemiddeld 2I tweets per naar haar 283 volgers, Janny Joosten-Leijendekker (ChristenUnie) 2I tweets per dag naar slechts I37 volgers en Angelien Eijsink (PvdA) die nog altijd 8 tweets per dag naar niet meer dan 75 volgers stuurde.

4 In België kunnen kiezers meerdere voorkeurstemmen uitbrengen, maar in de praktijk is dat een klein aantal en blijft de logica van de 'ballot position'-theorie houdbaar (cf. Thijssen \& Jacobs, 2004).

5 Een andere mogelijkheid om dit te modeleren en partijspecifieke kenmerken te verdisconteren is het schatten van een fixed-effect OLS-model met het percentage stemmen van het partijtotaal als afhankelijke variabele en dummy's voor de partij, die worden geïnteracteerd met bijvoorbeeld de dummy voor lijsttrekkers. Een dergelijk model hebben we ook geschat en levert vergelijkbare verbanden op. Het belangrijkste verschil is dat al bij een lager aantal volgers het effect van het aantal tweets statistisch significant is.

6 De belangrijkste onafhankelijke variabelen vertonen lage correlaties onderling, waardoor het gevaar van multicollineariteit miniem is. Van de controlevariabelen zijn de twee variabelen die het aantal keren 
38 | Tijdschrift voor Communicatiewetenschap - 42 [I] 20 I4

dat een kandidaat in de krant genoemd worden en de lijsttrekkerdummy wel sterk gecorreleerd. De lijsttrekkereffecten worden echter volledig weggefilterd door deze variabele op te nemen in het random deel van het model. Dat de twee 'krantenvariabelen' mogelijk multicollineair zijn betekent dat we moeten oppassen met de interpretatie van hun exacte coëfficiënten, maar aangezien dit niet de kernvariabelen zijn, maakt dit weinig uit voor onze analyse.

7 In totaal elf kandidaten hebben na de verkiezing dusdanig veel berichten geplaatst dat op het moment van meting het Twitterarchief niet ver genoeg terugging. We hebben hen een score van 5000 tweets gegeven, een getal dat dichtbij het aantal tweets van de meest actieve kandidaat (Attje Kuiken) ligt. Het weglaten van deze kandidaten zou een sterke 'selection bias' betekend hebben. We weten dat ze zeer actief zijn op Twitter alleen niet precies hoeveel. Echter de resultaten zijn niet substantieel anders als we bijvoorbeeld 2000 in plaats van 5000 tweets invullen.

8 Analyses met enkel de kandidaten met een Twitteraccount tonen dezelfde resultaten. De p-waarden zijn wat hoger, aangezien de steekproefgrootte daalt.

9 Gemeten door elke kandidaat op te zoeken onder 'landelijke dagbladen' in de krantendatabank LexisNexis.

IO De intercodeurbetrouwbaarheid was $98.2 \%$ en de Krippendorffs Alpha 0.90 (zie De Swert, 20I2), wat logischerwijs hoog is gegeven de strikte criteria. Bij verschillen in de codering (bijvoorbeeld bij opinieleiders) is middels consensus een code toegekend.

II Andere factoren zoals geografische representatie en specialismen van kandidaten konden we niet opnemen in de analyse. Ze worden wel deels opgevangen door de andere controlevariabelen, met name de mediavariabelen.

I2 Het model zoals gepresenteerd in tabel 2 is ook berekend met enkel de hoofdvariabelen en de controlevariabelen (zonder hogere-ordetermen). Dat model laat een positief verband zien tussen het aantal tweets en voorkeurstemmen $(\mathrm{B}=\mathrm{I} 6.8 ; \mathrm{p}=0.024)$. Het gepresenteerde model laat echter zien dat het verband niet zo algemeen geldend is als wellicht gesuggereerd zou worden door dat model. Het model zoals gepresenteerd, maar dan zonder hogere-orde-interacties laat eveneens vergelijkbare resultaten zien met een duidelijk interactie-effect tussen het aantal tweets en volgers $(B=I I ; p=0.000)$.

I3 Wanneer we de coëfficiënten doorrekenen en invullen voor de kandidaten, lijkt dat geen kandidaat verkozen zou zijn dankzij zijn of haar Twittergebruik. Vooral kandidaten die de voorkeursdrempel sowieso al haalden, lijken veel te profiteren. Voor 20 Io ging het daarentegen om twee kandidaten (cf. Spierings \& Jacobs, 2013).

I4 Een eventueel effect van Twitter zal ook steeds een onderdeel zijn van een langere causale keten: ervaring en professionele ondersteuning inzake Twittergebruik zullen wellicht dat gebruik effectiever maken. Dit was duidelijk het geval voor de verkiezingen van 2012 waar veel partijen voor het eerst Twitterondersteuning boden (cf. Bleijerveld, 2I-8-20I3). 